\title{
GEOGRAFIA, NOVAS TECNOLOGIAS E ENSINO: (RE) CONHECENDO 0 "LUGAR" DE VIVÊNCIA POR MEIO DO USO DO GOOGLE EARTH E GOOGLE MAPS
}

\section{GEOGRAPHY, NEW TECHNOLOGIES AND EDUCATION: (REVERSE SPEED) KNOWING THE "PLACE" OF EXPERIENCE BY MEANS OF THE USE OF THE GOOGLE EARTH AND GOOGLE MAPS}

\author{
Jonas Marques da Penha', Josandra Araújo Barreto de Melo \\ ${ }^{1}$ Universidade Estadual da Paraíba (UEPB), Campina Grande, PB, Brasil
}

\author{
Correspondência para: Josandra Araújo Barreto de Melo (ajosandra@yahoo.com.br) \\ doi: $10.12957 /$ geouerj.2016.13119 \\ Recebido em: 1 out. 2014 | Aceito em: 2 mai. 2016
}

\section{RESUMO}

Tendo em vista que atualmente não se tem como dissociar educação e novas tecnologias, visto que cada vez mais cedo os jovens têm feito uso de ferramentas tecnológicas, o presente trabalho teve como objetivos analisar a experiência desenvolvida no ensino de Geografia, objetivando o conhecimento do "lugar" enquanto espaço de vivência dos alunos, a partir do uso de novas tecnologias, mais especificamente do Google Earth e do Google Maps e do trabalho de campo. O trabalho foi desenvolvido em 2013, com a turma do $8^{\circ}$ Ano "C" da E.E.E.F. Maria Emília Oliveira de Almeida, localizada no bairro Presidente Médici, na cidade de Campina Grande/PB. Com a pretensão de alcançar os objetivos teve-se como foco a Pesquisa-Ação. Para tanto, se buscou envolver a comunidade escolar ao processo. Trabalhou-se a partir de revisões teórico-bibliográficas; pesquisa quantitativa; aulas expositivas dialogadas; pesquisa virtual no laboratório de informática, utilização dos softwares Google Earth e Google Maps; aula de campo; registros fotográficos, anotações e discussões e; socialização dos resultados na mostra pedagógica da escola. Constatou-se o fascínio juvenil pelas novas tecnologias, além da forte presença de tais ferramentas inovadoras no convívio diário dos docentes.

Palavras-chave: Pesquisa-Ação; Ensino de Geografia; Novas Tecnologias; Lugar; Cotidiano.

\begin{abstract}
Considering that currently there is no way to separate education and new technologies, since each time more early the young man makes use of new technologies, the present work had as objective to analyze the experience developed in the education of Geography, being objectified the knowledge of the "place" while space of experience of the pupils, from the use of new technologies, more specifically of the Google Earth and the Google Maps and the work of field. The work was developed in 2013, with the group of $8^{\circ}$ Year "C" of the E.E.E.F. Maria Emilia Oliveira de Almeida, located in the city of Campina Grande/PB, having as research object the quarter Presidente Médice, in which the school is embedded. Aiming to achieve the objectives outlined we used the action research seeking to involve the school community in the process. The work was developed from literature reviews; quantitative research; expository and dialogued lessons; virtual research in the computer science laboratory, use of software's Google Earth and Google Maps; field lesson; photographic registers, notations and theoretical discussions $e$; socialization of the results in the pedagogical sample of the school. The youthful allure for the new technologies was evidenced, beyond, of the strong presence of such innovative tools in the daily conviviality of the teachers.
\end{abstract}

Keywords: Research-Action; Education of Geography; New Technologies; Place; Daily.

\section{INTRODUÇÃO}

A escola pensada no contexto contemporâneo representa um espaço de convergência de indivíduos oriundos de contextos socioeconômico, étnico e cultural distintos, o que enriquece o ambiente escolar 
com sua diversidade, diferente de outrora, quando o público escolar era seletivo e a escola era para poucos. No entanto, a profissão de professor torna-se um desafio constante na busca de compreender e intervir didático-metodologicamente, de forma a atender tal pluralismo.

$\mathrm{Na}$ atualidade, em que se vivencia o período técnico-científico-informacional, não tem como dissociar educação e novas tecnologias, seja no ambiente escolar (currículo formal) ou cotidianamente (currículo informal), visto que, cada vez mais cedo, os jovens vêm utilizando tecnologias. A internet, por exemplo, disponibiliza uma infinidade de informações e pode ser utilizada como recurso pedagógico no auxílio do ensinar-aprender, da construção do conhecimento, conforme se procura analisar neste trabalho.

Por outro lado, o espaço escolar e a comunidade são ambientes de convergências multiculturais, com indivíduos advindos de contextos socioeconômicos e culturais distintos, mas que passam a usufruir do mesmo espaço geográfico. A diversidade, motivo de muitos conflitos, associada a alguns fenômenos como a evasão escolar, a falta de interesse pelo estudo e/ou as dificuldades de compreensão dos conteúdos têm sido motivos de inquietações e para repensar a prática docente.

Nesse contexto, surgiu a ideia de utilizar as novas tecnologias - Google Earth e Google Maps, associadas à aula de campo como ferramentas didático-pedagógicas no ensino de Geografia, de forma a relacionar os conteúdos programáticos com o cotidiano do alunado, fazendo-se uso do conhecimento e reconhecimento do espaço vivido na perspectiva da interação com os fundamentos geográficos, de forma a possibilitar a construção dos conceitos e um ensino com significância para os alunos.

A escolha do Lugar como âncora para o desenvolvimento das atividades se deu devido às estreitas relações de identidade existentes entre tal categoria de análise e o público discente. A partir do espaço de vivência dos estudantes/pesquisadores - o Lugar pode-se trabalhar de forma mais aproximada e significativa as categorias e os conceitos geográficos, como por exemplo, o Território, a Paisagem e a Linguagem Cartográfica: Escala Numérica, Escala Gráfica, Perímetro e Cálculo de Área. 
As abordagens conceituais e discussões ocorreram envolvendo e valorizando a gama de conhecimentos trazidos pelos alunos, a partir do contato com o espaço e a troca de experiências vivenciadas. Corroborando com a teoria de Vygotsky, onde a aprendizagem se dá a partir da mediação do outro, desenvolveu-se um trabalho de aproximação entre as categorias, conteúdos e cotidiano dos alunos, tendo o professor exercido uma postura mediadora, provocando, questionando, sugerindo, acompanhando e, assim, colaborando para a construção coletiva do conhecimento.

Mediante o exposto, o presente trabalho tem como objetivos analisar a experiência desenvolvida no ensino de Geografia, objetivando o conhecimento do "lugar" enquanto espaço de vivência dos alunos, a partir do uso de novas tecnologias, mais especificamente do Google Earth e do Google Maps, associado ao trabalho de campo.

\section{CAMINHOS DA GEOGRAFIA: UM BREVE HISTÓRICO DA CIÊNCIA}

O processo de institucionalização da Geografia no Brasil se iniciou em 1934, com a vinda dos geógrafos Franceses Pierre Deffontaines e Pierre Mombeig, discípulos de Paul Vidal de La Blache, com o propósito da criação do curso de Geografia na Faculdade de Filosofia, Ciências e Letras/Universidade de São Paulo - FFCL/USP e, posteriormente, na Faculdade Nacional do Rio de Janeiro - FNRJ. Em seguida, ocorreu a fundação da Associação dos Geógrafos Brasileiros - AGB, em 1935; a criação do Conselho Nacional de Geografia - CNG, em 1937 e do Instituto Brasileiro de Geografia e Estatística - IBGE, em 1939. Uma Geografia a serviço do poder hegemônico, do Estado.

Anterior a Universidade de São Paulo - FFCL/USP, fundada em 1934, a Geografia já era ensinada, no Colégio Pedro II, no Rio de Janeiro, por profissionais advindos de outras áreas do conhecimento. "Eram professores de Geografia, principalmente, advogados, engenheiros, médicos e seminaristas" (PONTUSCHKA et al., 2009, p. 45), e tinham como objetivo a discrição dos recursos naturais do Brasil, propagando a nacionalidade e o nacionalismo. “...foi em 1837, no Colégio Pedro II que a Geografia, pela primeira vez, torna-se uma disciplina estudada na escola” (CASSAB, 2009, p. 46). 
Verifica-se, assim, que a Geografia foi ensinada antes mesmo de ser considerada uma disciplina sistematizada, mas convém ressaltar que a fundação da FFCL/USP teve papel fundamental no desenvolvimento da ciência Geográfica no país e na formação de professores para o ensino da disciplina. "Em 1936, foram formados os primeiros professores licenciados para atuar no ensino secundário" (CASSAB, op. Cit., p. 47).

Antes de haver geógrafos, já havia professores que lecionavam Geografia. Hoje, o professor de Geografia nem mesmo é considerado Geógrafo, a partir da dicotomia bacharel/licenciado. E a própria Licenciatura no contexto da Universidade, na maioria dos casos, prepara mais os alunos para a pesquisa em subáreas da Geografia, que para o próprio ensino, constituindo-se uma prática teórica do ensino, mas, muito pouco um ensino da prática. Portanto, nesse contexto, surge a problemática do ensino da Geografia, a dificuldade do exercício da transposição didática como prática pedagógica, do científico para o escolar.

Na década de 1970, a disciplina de Geografia na escola foi substituída pelo componente de Estudos Sociais, “... o governo militar passou a considerar que a Geografia nada acrescentava aos seus objetivos educacionais" (CASSAB, 2009, p.48). Era um sinal de mudança no olhar geográfico, incomodando o "Regime". No final dessa mesma década, vieram à tona nas Universidades e nas Escolas os debates ancorados na "Geografia Crítica", marxista, criticando a "Geografia Clássica" e "Teorético-quantitativa", respectivamente representada por enciclopedismo e instrumento ideológico.

A partir da década de 1980, a "Geografia Escolar" ganhou no seu currículo novos conteúdos, temas focados nas relações entre sociedade, trabalho e natureza. A dificuldade encontrada na implantação dessa Geografia Crítica na Escola estaria na formação dos professores que, enraizados no modelo clássico enciclopédico, acabavam por reproduzir essa prática em sala de aula, o que até hoje não mudou muito.

Na década de 1990, se iniciaram fortemente nas Universidades e nas Escolas as discussões acerca da "Geografia Humanística" e o ensino de Geografia ganhou uma nova roupagem. Essa ciência se 
apropriou do método fenomenológico hermenêutico e passou a valorizar o ensino a partir do espaço vivido do aluno, do lugar. Teoricamente, a relação professor-aluno seria harmônica e fundamental para a construção do conhecimento, tornando a Geografia mais interessante, já que partiria do conhecimento prévio dos alunos e com conteúdos mais próximos da realidade destes. Nesse contexto, emergiram os Parâmetros Curriculares Nacionais - PCN, um passo importante na forma de como construir o conhecimento, especialmente a partir da disciplina "Geografia". Para o Ensino Fundamental, os PCNs de Geografia sugerem:

...um trabalho pedagógico que visa à ampliação das capacidades dos alunos do ensino fundamental de observar, conhecer, explicar, comparar e representar as características do lugar em que vivem e de diferentes paisagens e espaços geográficos (BRASIL, 1998, p. 15).

Estes aspectos podem ser relacionados a este momento de uma Geografia mais "a serviço do ser humano", preocupada não apenas com o material, mas com a percepção humanista com a ênfase na experiência vivida nos espaços e lugares, buscando a compreensão do todo a partir do que está próximo, ao alcance dos olhos, das paisagens; das mãos; do espírito. Sendo assim, questiona-se como vem se materializando as propostas dos PCN e as teorias elencadas, analisadas e discutidas no âmbito acadêmico da Geografia.

\section{O Uso das Categorias de Análises Geográficas no Ensino Fundamental}

Professores que atuam com a Geografia Escolar precisam assumir posturas de profissionais mediadores na construção do conhecimento, utilizando-se das ferramentas de sua ciência, (teorias, métodos, recursos didáticos, conceitos geográficos e outras), no intuito de contribuir com a formação de indivíduos para a vida. "A finalidade de ensinar Geografia para crianças e jovens deve ser justamente a de ajudá-los a formar raciocínios e concepções mais articulados e aprofundados a respeito do espaço" (CAVALCANTI, 1998, p. 24).

No caso da educação de jovens, o público alvo trata-se de pessoas com certa vivência, detentoras de muitos conceitos já formados, o que torna delicada a intervenção, necessitando de conhecimentos prévios do contexto socioespacial, no qual tais alunos estão inseridos, bem como de didática apropriada 
para intermediar e interagir diante das diversidades étnicas e culturais convergentes na sala de aula. De acordo com Lana de Souza Cavalcanti,

Entre o homem e o lugar existe uma dialética, um constante movimento: se o espaço contribui para formação do ser humano, este, por sua vez, com sua interação, com seus gestos, com seu trabalho, com suas atividades, transforma constantemente o espaço (CAVALCANTI, 1998, p.24).

Entender o espaço geográfico é entender as ações humanas sobre este espaço, a dinâmica da vida, da existência e conseguir enxergar-se como parte integrante e agente modificador do mesmo. Em contrapartida, essa atitude ajuda a concretizar a Geografia, na escola, enquanto ciência e disciplina escolar importante. Pensando o espaço como o lugar dos acontecimentos resultantes das interações do ser humano com a natureza, natural ou modificada, pode ser visualizado possibilidades de interagir ou discutir os conteúdos na perspectiva da categoria, espaço e das demais subdivisões, especialmente a categoria lugar.

Buscando-se resgatar o valor do ensino de Geografia, necessita-se discutir as relações que as sociedades estabelecem em seus espaços. Os modos de ocupação, apropriação destes, as interações, até porque a dimensão social se constitui o cerne das dinâmicas dos territórios, das paisagens, das regiões, etc. Para melhor compreensão desse espaço uno e múltiplo, faz-se necessário a fragmentação do espaço, em subespaços. Nessa perspectiva, inserem-se as categorias de análise geográficas: território, região, paisagem, lugar, componentes do espaço geográfico. "O mundo encontra-se organizado em subespaços articulados dentro de uma lógica global" (SANTOS, 1988, p. 17).

As categorias de análise geográficas constituem os pilares de sustentação da Geografia enquanto ciência, elas representam os diversos olhares sobre o espaço. No entanto, nem sempre os profissionais do ensino de Geografia têm a formação necessária para trabalhar nessa perspectiva, conforme destaca Kaercher (2007, p.28) "Tudo cabe como sendo Geografia. Nós, de fato, falamos de tudo nas aulas, mas paradoxalmente, com pouca relação às categorias consideradas basilares à Geografia (espaço, território, região, paisagem, lugar)". 
As discussões conceituais acerca das categorias de análise geográficas agregadas aos conteúdos e percepções do cotidiano dos alunos repercutem positivamente, tanto na formação dos indivíduos, tornando-os conhecedores de si e da dinâmica espacial quanto para o fortalecimento científico da Geografia, na escola.

É importante ressalvar que, quanto mais cedo apresentar as categorias geográficas aos indivíduos, mais suas relações com estas serão ativas e conscientes. Segundo Tuan (1983, p.83), "a criança é o pai do homem, e as categorias perceptivas do adulto são de vez em quando impregnadas de emoções que procedem das primeiras experiências". É perfeitamente possível trabalhar a partir dessa perspectiva, das percepções do espaço vivido, junto a um público de jovens e adultos, usando suas experiências como ponto de partida para construção do conhecimento. Para Helena Copetti Callai,

O professor deverá propor o estudo que seja consequente para os alunos. E as experiências concretas deverão ter interligamento e coerência dentro do que é ensinado, pois o vivido pelo aluno é expresso no espaço cotidiano, e a interligação deste com as demais instâncias é fundamental para aprendizagem (Ibidem, p. 136).

Corroborando com Callai (op. Cit.), Pontuschka et al (2009) afirmam que, quanto à prática do ensino de Geografia, as observações informais e também sistemáticas de fotos ou fenômenos do cotidiano, a partir da capacidade de registrá-los e a concepção que o sujeito tem sobre algo em dado momento, são procedimentos que alargam e aprofundam a reflexão à medida que, confrontada com um conhecimento mais elaborado, resulta na produção de um novo conhecimento. Exemplificando com as palavras de Pontuschka et al.:

(...) fazer leituras de imagens, habituar-se a ler várias modalidades de textos e integrá-los aos conhecimentos possuídos; ser capaz de utilizá-los em situações externas à escola, portanto, em situações de vida; observar um fato isolado e poder contextualizá-lo no tempo e no espaço (PONTUSCHKA et al., op. Cit., p.108.).

Tais experiências nas relações com o espaço, muitas vezes, ocorrem de forma empírica no cotidiano dos alunos, podendo ser valorizadas na sala de aula através da utilização pelo professor das discussões acerca desses conhecimentos, construindo um elo entre as percepções cotidianas e o conhecimento científico sistematizado do currículo escolar, contribuindo para a formação desses indivíduos, fazendo a ciência desempenhar o seu papel social. "Os professores precisam perceber que seu papel no processo 
de democratização da sociedade consiste em, principalmente, desenvolver uma prática pedagógica não alienante, mas conscientizadora" (ALMEIDA, 1991, p.89).

O professor de Geografia deve se empenhar no ensino de uma Geografia crítica, questionadora e esclarecedora, capaz de libertar o indivíduo para a vida e galgar no sentido da democratização da sociedade.

\section{Escola, Educação e Tecnologia: caminhos paralelos ou convergentes?}

Difícil desvincular tecnologia de educação, até porque desde os primórdios as técnicas, mesmo rudimentares, eram aprendidas e ensinadas, informalmente, na labuta cotidiana em busca da sobrevivência. "O ato de agir sobre a natureza, adaptando-a as necessidades humanas é o que conhecemos pelo nome de trabalho" (SAVIANI, 1994, p. 152). O trabalho que outrora era pensado e desenvolvido empiricamente torna-se dependente do ensino institucionalizado, na escola. É na escola que se aprimoram as técnicas, que se prepara ou se programa o contingente populacional para 0 mercado.

Segundo Saviani (op. Cit.), a escola surge para atender a ociosidade de uma classe que se sobrepõe a outra, estudar significava não precisar trabalhar. No contexto atual, com o avanço tecnológico desencadeando o desemprego estrutural, estudar deixa de ser ócio para ser necessidade básica. O poder hegemônico prescreve doses homeopáticas de educação a sociedade, na escola, o suficiente para atender a demanda da produção e a acumulação de capital por uma minoria.

Essa necessidade de mão-de-obra especializada abre janelas para a ascensão profissional, conforme analisa Saviani (op. Cit.),

Quanto mais avança o processo urbano-industrial, mais se desloca a exigência da expansão escolar. Por aí é possível compreender exatamente porque esta sociedade moderna e burguesa levanta a bandeira da escolarização universal, gratuita, obrigatória e leiga. A escolaridade básica deve ser estendida a todos (ibidem, p.156). 
Nesse contexto, a educação escolar torna-se o parâmetro de determinada sociedade, se sobrepondo as demais formas de educação e com o acúmulo de funções, haja vista que a escola, pensada no contexto contemporâneo, tem absorvido diversas responsabilidades que, muitas vezes, deveriam pertencer a outros grupos da sociedade ou, pelo menos, haver parcerias mais efetivas, principalmente com a família. “...também se reivindica que a escola, nos eu interior, assuma encargos que extrapolam aquilo que é especificamente pedagógico" (SAVIANI, op. Cit., p.158).

O professor(a) se depara com um espaço, a sala de aula, convergente de uma imensa diversidade socioeconômica e cultural, bem diferente de outrora, quando o público escolar era seletivo e, portanto, para poucos. Nesse contexto, o professor atua desempenhando vários papéis, num palco com plateia multicultural e dispersa.

O aluno, mediante as aparições repentinas de novas tecnologias, tem cada vez mais acesso as informações prontas e apresentadas de forma atrativa, lúdicas, etc. bem mais interessantes que as aulas tradicionais incidindo no questionamento: a escola que prepara o cidadão para viver em sociedade está equipada para acompanhar o avanço dessa mesma sociedade? Tal indagação parte da verificação de que os aparatos tecnológicos que a escola ajuda a desenvolver, com a produção de material humano qualificado, não retornam a este espaço de forma significativa, na forma de recursos didáticos, mas estão presentes no cotidiano do alunado enquanto produto de consumo, muitas vezes alienado.

\section{Espaço Escolar, Ensino e Novas Tecnologias}

Na atuação como regente deve haver troca e não apenas transposição de conhecimentos. Dessa forma, certamente, tenderá a valorizar e provocar discussões em sala de aula, explorando as diversas culturas coexistentes, os conceitos atribuídos empiricamente pelos alunos a termos, temas e conteúdos propostos e as representatividades de determinados objetos e/ou ações existentes e percebidas nos respectivos espaços vividos. “(...) a percepção é o processo pelo qual as informações sobre a realidade são extraídas e recebidas pelo ser humano, estar-se também dizendo que, desde sua origem, ele constrói suas relações com o mundo, incorporando-o" (KIMURA, 2008, p. 46). 
Portanto, trabalhando em sala de aula os conteúdos propostos, a partir da percepção que os alunos têm do espaço vivido, cotidiano, pode-se elevar essa percepção empírica do alunado a um elaborado e sistematizado conhecimento, o cientifico.

Tal conduta profissional, elo entre o percebido e o real, proporciona ao professor a análise, reflexão e interpretação de realidades e percepções diferentes da sua, o que resulta num aprendizado informal, que pode lhe dar suporte na intermediação das discussões, mediante diferentes ópticas de análises e interpretações do mundo.

Para Kimura (2008, p. 46), "a aprendizagem pode ser entendida como o processo pelo qual o ser humano percebe, experimenta, elabora, incorpora, acumula as informações da realidade transformadas em conhecimento". Para tanto, a realidade vivida e percebida pelos alunos precisa ser refletida no espaço escolar para que os mesmos sintam-se inseridos.

Corroborando com Carraro (2005) apud Teruya et al., (2013), “(..) os jovens percebem o espaço escolar como um cotidiano enfadonho". Não se sentem atraídos, o que repercute diretamente na qualidade do aprendizado, no comportamento e, consequentemente, no rendimento intelectual na escola. Pode-se, em alguns aspectos, comparar o espaço escolar com o que Ana Fani Alessandri Carlos chama de não lugar, “(...) espaço baseado na não-identidade e no não-reconhecimento” (CARLOS, 2007, p.61).

O processo ensinar-aprender requer dos profissionais de educação o conhecimento da realidade socioeconômico e cultural dos alunos em questão, além da humildade em dividir o palco, sala de aula, com os demais atores e a utilização de recursos e metodologias que aproximem a discussão ao cotidiano dos mesmos. Para Almeida (1991):

Através de sua própria prática, cada professor devera buscar os caminhos que atendam ás peculiaridades de sua realidade escolar procurando soluções mais eficazes para lidar com os problemas próprios da situação, tornando-se um verdadeiro profissional na arte de educar. (ibidem, p. 87). 
É muito mais interessante aprender quando os conteúdos fazem parte do cotidiano, quando se relacionam com o que acontece próximo, e que realmente seja relevante para o indivíduo diante de suas identidades em meio ao ciclo social. Neste panorama, deve-se destacar a influência das novas tecnologias no cotidiano da maioria dos alunos. "(...) os sites de relacionamento, blog, chats, e-mail, vem ganhando espaço no cotidiano das pessoas que possuem acesso a essas tecnologias" (PINHO et al, 2013, p.66).

Acesso e direcionamento para o uso dessas novidades que tem sido negligenciadas no ambiente escolar. Segundo Teruya et al (2013),

Utilizar a mídia no espaço escolar, como mediadora para produção de conhecimento ou como suporte para apresentação de eventos sociais, políticos, culturais, físicos e mentais são duas das muitas possibilidades para se articular os usos da mídia e seus produtos para o processo de ensino e aprendizagem (ibidem, p.80).

O discurso acadêmico tem diversas teorias e métodos para a prática pedagógica, no entanto a realidade escolar é um pouco diferente, a maioria das escolas das redes escolares e seus respectivos professores se deparam com paradigmas internos e externos ao ambiente escolar, que acarretam dificuldades no processo ensino-aprendizagem.

Segundo Almeida (op. Cit., p. 84), “(...) os professores atuantes nas redes de ensino não acompanharam essa evolução (quanto à abordagem teórico-metodológica e seu objeto de estudo), permanecendo presos aos conteúdos dos antigos planos e livros didáticos". Dessa forma, professores se submetem a lecionar aulas que não são suas; a utilizar métodos mais cômodos. Ao esboçar as críticas a essa categoria não nos esqueçamos do contexto no qual o mesmo se insere, é obvio a sede de mudança, mas, esta não pode nem dever ser unilateral.

O espaço escolar pelo seu dinamismo e a quantidade de variáveis existentes, torna-se um campo de múltiplas possibilidades de estudos e pesquisas. Cada compartimento, dependendo de sua estrutura e funcionalidade, o olhar do educador pesquisador pode identificá-lo como possível barreira na construção do conhecimento e, principalmente, buscar adequá-lo à realidade do público alvo, o alunado. 
Afinal, "Um dos fins declarados do ensino em geral é prolongar a vida concreta do aluno..." (BRABANT, 1989, p. 16).

Trabalhar com educação requer, dentre outras competências, um exercício diário de observações e leituras do presente imediato, da dinâmica, fruto das múltiplas relações entre pessoas de diferentes contextos, mas que convergem no mesmo espaço afim de objetivos semelhantes, à busca pela construção do conhecimento. “A ideia é ressaltar a importância da pesquisa na construção de uma atitude cotidiana de compreensão dos processos de aprendizagem e desenvolvimento dos alunos e de busca de autonomia da interpretação da realidade" (PONTUSCHKA et al, 2009, p. 95.).

Diante desse panorama, o educador do século XXI deve repensar sua prática pedagógica, devendo ter como desafio buscar se integrar com a geração digital, pois a sociedade está mais complexa e se transforma constantemente e a escola deve acompanhar as mudanças, deixando de ser um espaço cheio de paradigmas. Segundo Marc Prensky (2001):

Os professores de hoje têm que aprender a se comunicar na língua e estilo de seus estudantes. Isto não significa mudar o significado do que é importante, ou das boas habilidades de pensamento. Mas isso significa ir mais rápido, menos passo-a-passo, mais em paralelo, com mais acesso aleatório, entre outras coisas (ibidem, p.4).

Dessa forma, é importante também que os profissionais da educação entendam que as novas tecnologias vinculadas a novas metodologias de ensino podem auxiliar na sua prática pedagógica, ajudando a despertar o interesse e a criatividade dos alunos quanto aos conteúdos estudados e, assim, contribuir para que os conhecimentos sejam compartilhados e construídos em meio a cooperação e tornar a aprendizagem mais significativa.

Deve-se estar aberto para interagir e intermediar as avalanches de informações e choques culturais existentes no espaço escolar. "Conhecer a organização do espaço escolar e as relações entre os sujeitos é uma necessidade, na medida em que a aula não é um acontecimento isolado de uma sala, mas está inserida no espaço social de uma instituição de ensino" (SATO; FORNEL, 2010, p. 53). Trata-se de um laboratório de análise contínua, onde mesmo repetindo os mesmos métodos, sempre terá dinâmica e resultados diferentes. 
Muitas vezes os recursos fruto das novas tecnologias são vistos como ferramentas capazes de resolver os problemas da educação na escola. Sabe-se que, mais do que os recursos, deve-se mudar a metodologia de trabalho.

\section{METODOLOGIA}

O presente trabalho foi desenvolvido a partir da intervenção didático-pedagógica realizada na turma do 8º Ano "C", da E.E.E. F. Maria Emília Oliveira de Almeida, localizada na Zona Sul da cidade de Campina Grande/PB, no Bairro Presidente Médici.

A turma em que foi realizado o trabalho é relativamente pequena, mas com aspecto comportamental preocupante. É composta por alunos, em sua maioria, residentes nas suas proximidades e que se encontram dentro da faixa etária idade-série apropriada e oriundos de famílias de baixo poder econômico, filhos de assalariados.

Buscou-se desenvolver as intervenções numa perspectiva interdisciplinar. Para tanto, se contou diretamente com a participação das professoras dos componentes curriculares Língua Portuguesa, Artes e Matemática, com o apoio da gestão escolar e demais docentes.

Com a pretensão de alcançar os objetivos propostos, buscou-se suporte em alguns métodos e discussões teóricas, tendo como foco a Pesquisa-Ação, na mesma linha de pensamento de Tripp (2005, p. 445) “(...) é principalmente uma estratégia para o desenvolvimento de professores e pesquisadores de modo que eles possam utilizar suas pesquisas para aprimorar seu ensino e, em decorrência, o aprendizado de seus alunos (...)". 
A premissa para o planejamento dessa intervenção didático-pedagógica foi repensar a prática docente e a possibilidade de proporcionar o ensinar-aprender com significado, contextualizando os conteúdos da disciplina em questão com a dinâmica cotidiana dos alunos, a partir da apropriação, conhecimento e reconhecimento do espaço vivido.

A metodologia aplicada foi revisão teórico-bibliográfica; pesquisa quantitativa, a partir da aplicação de questionários com 20\% do contingente discente da escola; aulas expositivas e dialogadas, com a apresentação e revisões conceituais; pesquisa virtual no laboratório de informática, visualização vertical do bairro e de pontos de referências significativos para o coletivo e/ou individualmente; análise de imagens de satélites exploradas dos aplicativos (Google Earth e Google Maps); aula de campo, no formato de pesquisa exploratória do espaço de vivência; registros fotográficos, esboço de croquis, anotações e discussões e; socialização dos resultados na mostra pedagógica da escola. $\mathrm{O}$ quadro 1 apresenta as atividades desenvolvidas e as ferramentas utilizadas no decorrer das intervenções na construção do conhecimento.

\begin{tabular}{|c|c|}
\hline $\begin{array}{l}\text { Pesquisa } \\
\text { quantitativa com } \\
\text { alunos da escola }\end{array}$ & $\begin{array}{l}\text { Aplicado um questionário com } 20 \% \text { do contingente discente, com conteúdo abordando questões acerca do contato dos } \\
\text { mesmos com as novas tecnologias, dentro e fora do espaço escolar. }\end{array}$ \\
\hline $\begin{array}{l}\text { Elaboração do } \\
\text { projeto }\end{array}$ & $\begin{array}{l}\text { Tabulação dos dados da pesquisa; } \\
\text { Revisão bibliográfica para elaboração do material a ser trabalhado; } \\
\text { Apresentação da proposta de trabalho ao corpo discente; } \\
\text { Instalação do aplicativo Google Earth nos computadores do laboratório; } \\
\text { Elaboração do projeto. }\end{array}$ \\
\hline Sala de aula & $\begin{array}{l}\text { Disponibilização e discussão do projeto; } \\
\text { Aulas expositivas dialogadas; } \\
\text { Tabulação e análises dos dados e registros da pesquisa de campo; Adaptação de mapas do Bairro Presidente Médici a } \\
\text { partir de imagens do Google Earth e Maps pelos alunos; } \\
\text { Confecção da maquete do bairro Presidente Médici. }\end{array}$ \\
\hline $\begin{array}{l}\text { Laboratório de } \\
\text { Informática: } \\
\text { Google Earth e } \\
\text { Maps }\end{array}$ & $\begin{array}{l}\text { Criação de uma pasta com o nome da turma; } \\
\text { Visualização de imagens de satélite; } \\
\text { Definição do perímetro do Bairro Pres. Médici; } \\
\text { Identificação dos templos religiosos; } \\
\text { Delimitação do perímetro do bairro; Localização dos templos religiosos; Elaborado o roteiro de visita (aula de } \\
\text { campo). }\end{array}$ \\
\hline $\begin{array}{l}\text { Aula de Campo: } \\
\text { (Pesquisa) }\end{array}$ & $\begin{array}{l}\text { Visita prévia, do professor orientador, aos templos no intuito de agendar a recepção; } \\
\text { Utilizado o roteiro pré-elaborado pela a turma; } \\
\text { Visitados os templos religiosos e limites do bairro; } \\
\text { Registrado as informações: anotações, croquis e registros fotográficos. }\end{array}$ \\
\hline Peça Teatral & $\begin{array}{l}\text { Criação do Roteiro; } \\
\text { Discussões e Ensaios. }\end{array}$ \\
\hline Socialização & $\begin{array}{l}\text { Exposição e apresentação da maquete do Bairro Presidente Médici; } \\
\text { Encenação teatral. }\end{array}$ \\
\hline Avaliação & Contínua, processual e pontual. \\
\hline Conteúdos & $\begin{array}{l}\text { Categorias de analises geográficas: Território, paisagem e lugar; } \\
\text { Linguagem cartográfica: Visão oblíqua (lateral) e visão vertical; Imagem tridimensional (real) e imagem } \\
\text { bidimensional (plano); Representação cartográfica; Legenda; Proporção e escala; Unidade de medidas métricas e } \\
\text { cálculo de área; Lateralidade, referências e orientação espacial. }\end{array}$ \\
\hline $\begin{array}{l}\text { Recursos } \\
\text { e } \\
\text { Materiais }\end{array}$ & $\begin{array}{l}\text { Textos didáticos; } \\
\text { Computadores - Internet - Softwares Google Earth e Google Maps; } \\
\text { Câmeras fotográficas digitais; } \\
\text { Isopor, tinta, pincel, régua, tesoura, cola, estilete, cartolina; }\end{array}$ \\
\hline
\end{tabular}




\section{Figurinos e material para montagem dos cenários (peça teatral)}

Quadro 1. Das atividades, conteúdos, recursos e materiais.

Fonte: Elaborado por Jonas Marques da Penha, a partir do relato da pesquisa in loco (2013).

A regência ocorreu levando-se em conta as propostas elencadas pelos Parâmetros Curriculares Nacionais de Geografia, mais especificamente dos $1^{0}$ e $2^{\underline{0}}$ eixos temáticos do Quarto Ciclo, correspondentes a $7^{\mathfrak{a}}$ e $8^{\mathrm{a}}$ série do ensino fundamental.

\footnotetext{
Sugere-se que os eixos de conteúdo se ancorem em temáticas relativas à presença e ao papel da sociedade e suas interações com a natureza, nas dimensões técnicas e culturais que envolvem a apropriação e a transformação dos territórios, o modo de produzir e pensar o mundo nas sociedades atuais (...) (BRASIL, 1998, p. 92).
}

Os trabalhos iniciaram-se com a abordagem da categoria de análise geográfica Lugar, numa perspectiva humanista. Neste caso, o lugar representado pelo espaço vivido, que é a categoria mais próxima do indivíduo, de onde emergem o mundo dos significados, dos conhecimentos cognitivos. Segundo Bock et al. (2002), os conhecimentos cognitivos têm origem a partir das primeiras relações de significado entre o ser e o mundo, que são os pontos de partida para a atribuição de outros significados.

\section{RESULTADOS E DISCUSSÕES}

\section{O Espaço Escolar e o Fascínio Juvenil pelas Novas Tecnologias}

A escola contemporânea tem dificuldades em acompanhar o ritmo evolutivo da tecnologia e se adequar as múltiplas identidades e identificações do alunado, principalmente dos jovens. Nesse sentido, o foco desta pesquisa foi investigar as relações entre os discentes e as novas tecnologias, de forma a utilizar esta relação para a dinamização do ensino de Geografia, tomando como âncora a categoria lugar.

Tendo em vista que hoje os alunos têm cotidianamente contato, fora do âmbito escolar, com algum tipo de mídia, as chamadas novas tecnologias e fazem uso destas, muitas vezes, indiscriminadamente ou meramente como entretenimento, acredita-se que tais recursos poderiam ser melhor explorados no 
ensino-aprendizagem, aproveitando o fascínio pré-existente e, até mesmo, o domínio da técnica habilidade de manuseio dos estudantes.

Entretanto, verifica-se que Kimura (2008. p. 58) tem razão quando afirma que "não se presta atenção no aluno como protagonista, ator do processo de aprendizagem e de pensamento". Já Prensky (2001) se refere ao alunado como "nativos digitais", habitualmente detêm com maiores facilidades o avanço tecnológico, e os professores como "imigrantes digitais", frutos de outra geração.

Em pesquisa in loco constatou-se que apenas 1,2\% dos alunos não tem acesso à internet, enquanto que $72 \%$ acessam diariamente, conforme Figura 1.

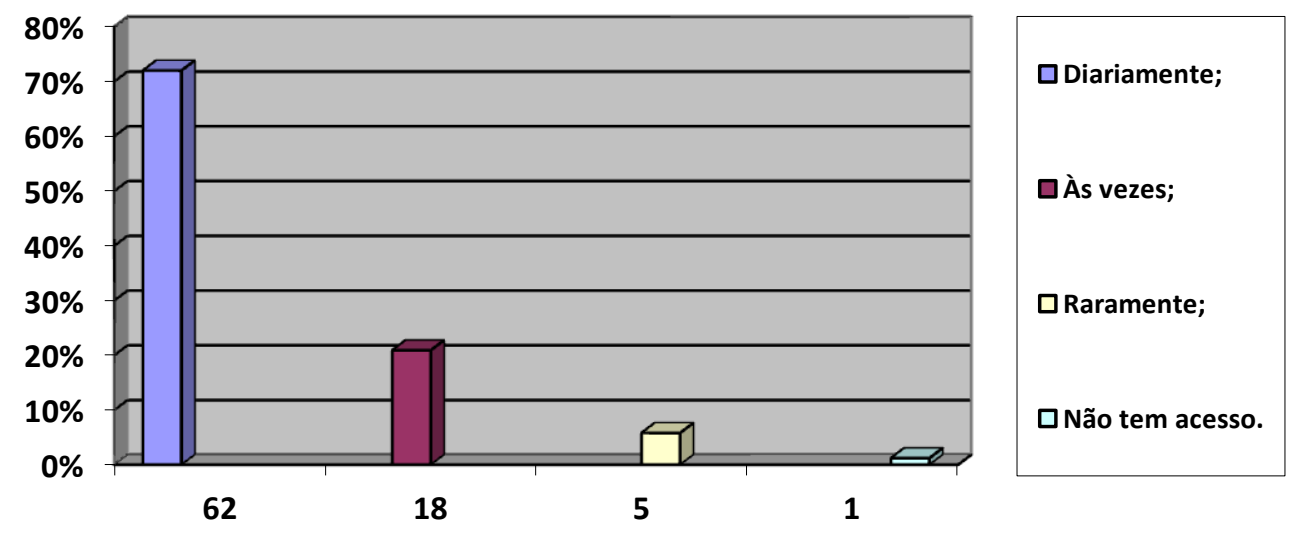

Figura 1. Frequência de uso da internet pelos alunos.

Fonte: in loco, pesquisa com alunos da E. E. E. F Maria Emilia O. Almeida, 2013.

Os dados da Figura 1 confirmam que se trata, realmente, de uma geração digital, entretanto também foi possível verificar que essa acessibilidade não tem sido orientada pelos professores (as), em aulas, como $31,4 \%$ dos discentes gostariam que acontecesse. 0 alunado afirma que $41,8 \%$ dos docentes nunca usam a informática (internet) em suas aulas, sendo um recurso utilizado, em sala de aula, esporadicamente por $51,2 \%$ do corpo docente.

Os dados da Figura 1 são complementados pelas informações dispostas no Tabela 1, referentes ao principal local de acesso à internet pelos alunos.

Tabela 1. Dos locais de acesso à internet pelos alunos. 


\begin{tabular}{lcc}
\hline Local de acesso & $\mathbf{N}^{\mathbf{0}}$ de alunos & $\%$ \\
\hline Em casa & 71 & $82,5 \%$ \\
Outros locais & 17 & $19,8 \%$ \\
Casa de amigos & 14 & $16,3 \%$ \\
Escola & 11 & $12,8 \%$ \\
Lan house & 08 & $9,3 \%$ \\
Não tem acesso & 01 & $1,2 \%$ \\
\hline
\end{tabular}

Fonte: Elaborado por Jonas Marques da Penha, a partir de pesquisa quantitativa, in loco (2013).

Apenas $12,8 \%$ dos alunos afirmaram que acessam a internet na escola. Se considerarmos que na escola não tem rede Wi-Fi para exploração desse recurso, e que o uso do laboratório de informática, pelos professores, segundo os alunos, (ver gráfico - 03) ocorre raramente ou nunca, pode-se ver esses acessos como possíveis problemas, na medida em que acontecem do celular, de forma indiscriminada e descontextualizada com as intencionalidades da sala de aula, comprometendo a concentração e, consequentemente, o aprendizado dos conteúdos que estão sendo trabalhados nas disciplinas.

Observa-se entre os estudantes que o número de acessos à internet a partir de ferramentas existentes em seus lares é grande, 82,5\%, um alerta para rever a prática docente e de inserir atividades condizentes com a realidade do público alvo. A Figura 2 apresenta resultados da supracitada pesquisa, in loco, destacando como é utilizado pelos alunos, o espaço virtual, na internet.
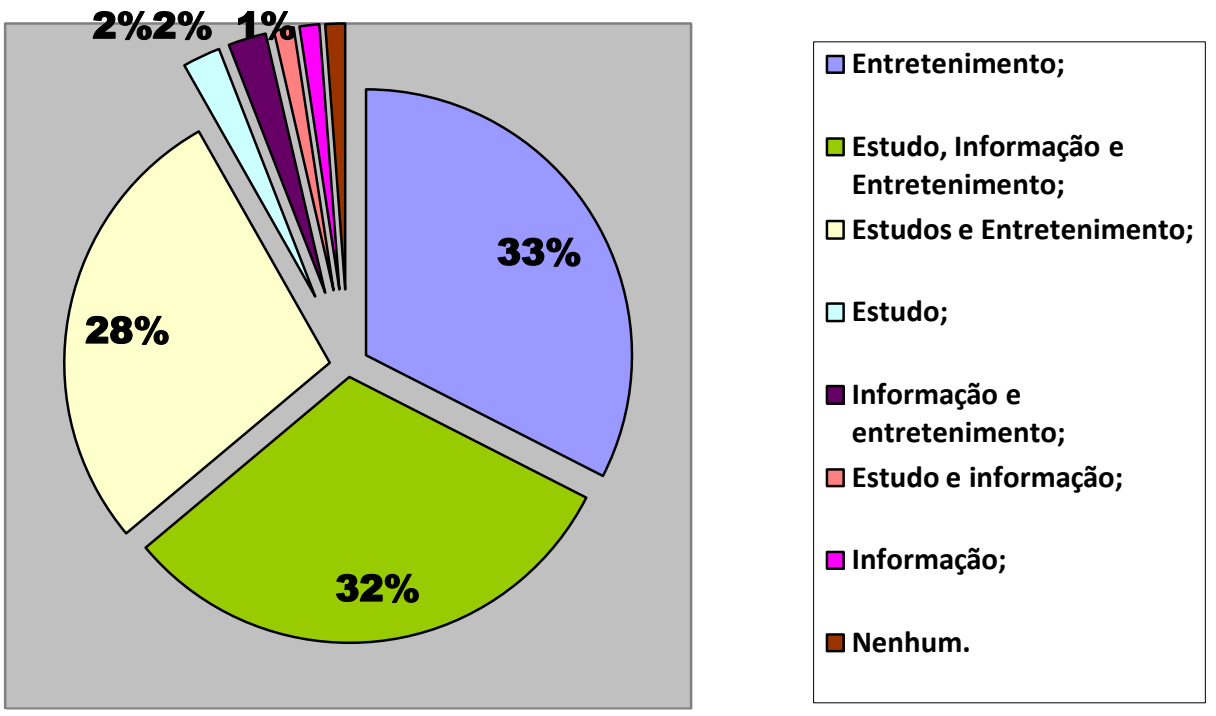

Figura 2. Uso da internet pelos alunos.

Fonte: Pesquisa, in loco, com alunos da E. E. E. F. Maria Emilia O. Almeida, 2013. 
Como a maioria dos alunos utiliza a internet apenas para entretenimento e a escola não consegue fazer uso da ferramenta no cotidiano, infere-se que a mesma se apresenta como uma instituição que não atende aos anseios do público contemporâneo, conforme compreensão expressa por Abramovay e Castro (2003) apud Lemos (2009, p. 42), "os alunos têm expectativa de que a escola tenha condições mínimas de acesso às novas tecnologias de informação e comunicação e que sejam instrumentalizados para usá-las". No entanto, se deparam com um contexto de ausência ou inoperância dos poucos recursos tecnológicos disponíveis e com aulas tradicionais e enfadonhas.

Questiona-se como fazer da escola um "lugar" para seus atores. Mesmo em uma escola que disponha de recursos como biblioteca, sala de vídeo, projetores e computadores com acesso à internet, como é o caso da escola em foco, há inversões do que é utilizado pelos professores em relação ao que os alunos gostariam que fosse trabalhado nas aulas.

Segundo os questionados, a prática dos professores é justamente o oposto do que eles esperam nas aulas. O trabalho com o livro didático, por exemplo, aparece na pesquisa como última opção dos alunos, com apenas 8,1\% das sugestões de aulas, em contrapartida, obteve 90,7\% afirmações de que a utilização dessa prática, pelos professores, ocorre frequentemente.

Já a sugestão de aulas com computadores e internet foi feita por $31,4 \%$ dos alunos, ao passo que foi mencionado por $41,8 \%$ dos estudantes que este tipo de aula nunca foi realizado em sala de aula pelos professores. Observando-se a Figura 3, fica confirmado o pouco uso da internet como recurso didático, cerca de $93 \%$ dos professores nunca utilizou ou raramente utiliza tal ferramenta na dinâmica de suas aulas. 


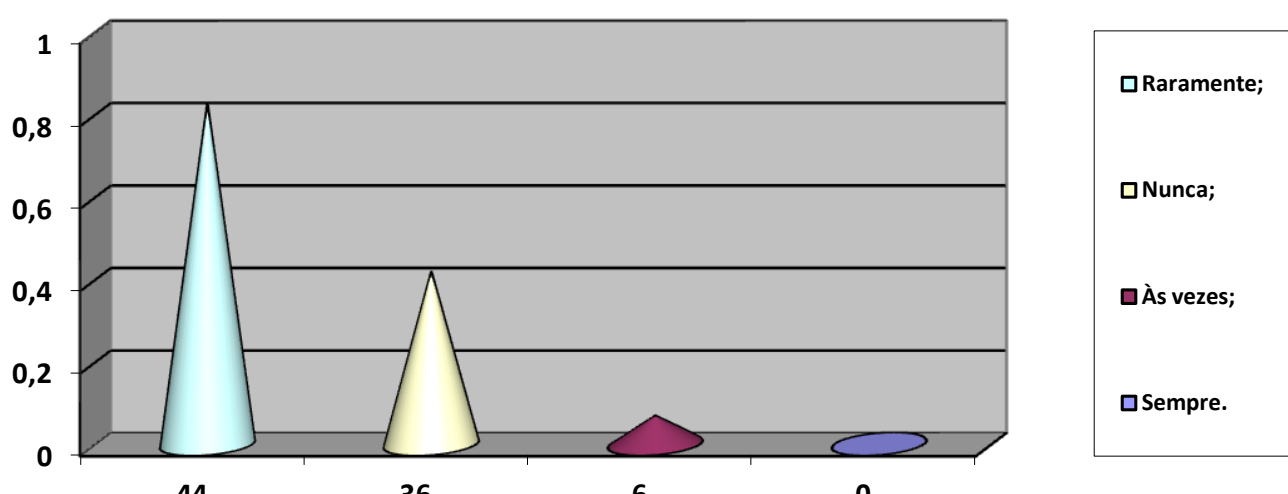

Figura 3. O uso, pelos professores (as), de computadores e internet em suas aulas, segundo alunos entrevistados. Fonte: Pesquisa, in loco, com alunos da E. E. E. F. Maria Emilia O. Almeida, 2013.

É importante lembrar que os professores não foram questionados quanto aos motivos dessa ausência e não se pretendem, no momento, adentrar a este mérito, a análise limita-se aos questionamentos respondidos pelos discentes.

Segundo Moran (2004, p. 2), "hoje, com a internet e a fantástica evolução tecnológica, podemos aprender de muitas formas, em lugares diferentes e de formas diferentes. A sociedade como um todo é um espaço privilegiado de aprendizagem". O professor, dessa forma, deve deixar de ser "o informador", passando a ser um articulador de aprendizagens.

Não se deve atribuir os problemas ou os possíveis méritos da educação só e exclusivamente ao professor, assim como, nessa profissão, não se podem ignorar os adventos da sociedade, pois é nela e dela que emergem os principais atores da escola, os alunos. "Algumas teorias pedagógicas, chamadas delicadamente por vários educadores de otimistas, destinam ao trabalho do professor uma tarefa de agente transformador da sociedade numa versão salvacionista, como se ele fosse até onipotente" (KIMURA, 2008, p. 55). Deve-se sim ter potencial para surpreender, mas isso não os coloca no patamar de super-heróis, que podem tudo, retirando as responsabilidades de outrem.

O uso de novas tecnologias não exclui as aulas de campo, mas minimiza a dependência de ter que se ausentar do espaço escolar, principalmente quando a escola não dispõe de pessoal para o apoio 
necessário. Nesse contexto, as observações in loco ocorreram em um único momento, porém foram previamente planejadas e a área virtualmente explorada.

\section{Conceitos e Categorias de Análise Geográficas}

Numa perspectiva interdisciplinar, o corpo docente se fez ciente e teve posse da ementa do desenvolvimento e cronograma do projeto, oportunizando a alguns professores colaborarem. Na disciplina Matemática, por exemplo, a professora trabalhou os conteúdos: proporção, regra de três simples, unidade de medidas e cálculo de área, temas fundamentais para a cartografia. Em Língua Portuguesa, a professora subsidiou na produção textual (peça), variações linguísticas, dentre outros aspectos explorados.

Religião discutiu a diversidade religiosa do Brasil e sua gênese. Ambos os conhecimentos serviram de suporte para ampliação, discussão e construção de conceitos geográficos. Em parceria com a Professora de História, organizou-se no espaço escolar uma palestra ministrada por lideranças e conhecedores da cultura religiosa brasileira. Uma contribuição no conhecimento, pelos alunos, dos grupos religiosos que compõem sua comunidade na esperança de desconstrução de "verdades prontas" e preconceitos existentes.

Não se enfrentou muitos problemas de ordem pedagógica, pois os conteúdos foram facilmente assimilados, provavelmente devido ao trabalho coletivo com os professores; também pelo fato da maioria dos discentes já fazerem uso da internet e; pela aproximação dos mesmos com o objeto de pesquisa e conteúdos abordados no dia a dia na sala de aula.

Percebeu-se que, no decorrer das etapas da pesquisa-ação, a relação dos alunos com os conteúdos e conceitos trabalhados tornou-se, cada vez mais, real, palpável e concreta.

\section{Lugar}


Nas discussões acerca do lugar, a partir da concepção dos alunos, os mesmos se sentiram à vontade para se expressarem. Descreveram com requinte de detalhes seus lugares. Empiricamente, tal subespaço já está imbuído no íntimo dos indivíduos, no entanto, banalizado, sem muita atenção. "O lugar se refere de forma indissociável ao vivido, ao plano do imediato. E é o que pode ser apropriado pelo corpo (...)" (CARLOS, 2007, p.19). Dele emana a energia que supre as necessidades espirituais, são nos lugares onde as pessoas se enxergam como humanos, servem e são servidos; que são vistos e compreendidos; onde espaço e indivíduos se misturam se tornando uno, dinâmico e interessante.

Vale ressaltar que a expressão espiritual aqui não é entendida numa configuração religiosa, uma vez que as religiões são confessionais e, por isso, usualmente, dogmáticas. Falamos, sim, de "necessidades espirituais como as que vão para além da materialidade do cotidiano; falamos das aspirações que se dão no coração e na alma de cada um, assim como na alma e no coração dos povos; aspirações de viver bem e em plenitude" (LUCKESI, 2011, p. 31).

O bairro, Presidente Médici, é um espaço comum aos alunos do projeto, no entanto, verificou-se que nem todos o conheciam ou davam atenção para algumas especificações peculiares do local, como por exemplo, a forte influência religiosa. Segundo pesquisa in loco, desenvolvida pelos discentes o bairro dispõe de 10 Templos Evangélicos, uma Igreja Católica, um Centro Espírita e um Terreiro de Umbanda.

A partir dos aplicativos Google Earth e Google Maps foi possível a aproximação dos atores com seu espaço vivido. De forma rápida, foi possível visualizar imagens do bairro possibilitando a análise das paisagens e o reconhecimento pelos alunos como parte integrante desse espaço geográfico. Entender o lugar é entender a si próprio, visto que espaço e ser humano formam uma unidade. Fundamentados no conceito de "lugar" proposto por Tuan (1983), pôde-se facilmente constatar relações socioespaciais de identificação do alunado com as paisagens. "O que começa como espaço indiferenciado transforma-se em lugar, à medida que o conhecemos melhor e o dotamos de valor" (TUAN, 1983, p. 6). 
A configuração de espaço enquanto lugar está ligado diretamente às relações de intimidade entre ser humano e paisagem, a sensação de pertencimento. Os comentários e as inquietações se multiplicavam quando as imagens eram aproximadas. Estavam ali as práticas cotidianas representadas em suas ruas, no campinho, na escola, no posto de saúde, na padaria, nos mercadinhos, e outras. "O lugar (...) (é) o ponto de práticas sociais específicas que nos moldam e nos formam e com as quais nossas identidades estão estreitamente ligadas" (HALL, 2006, p. 72). A relação com esse espaço de acontecimentos pelos indivíduos nele inseridos resulta na propagação e valorização das raízes culturais.

A partir das imagens de satélites e dos conhecimentos e percepções dos alunos, eles elencaram as ruas em ordem alfabética, os pontos de referências, traçaram o perímetro do bairro. Informações, posteriormente, utilizadas na confecção da maquete do bairro.

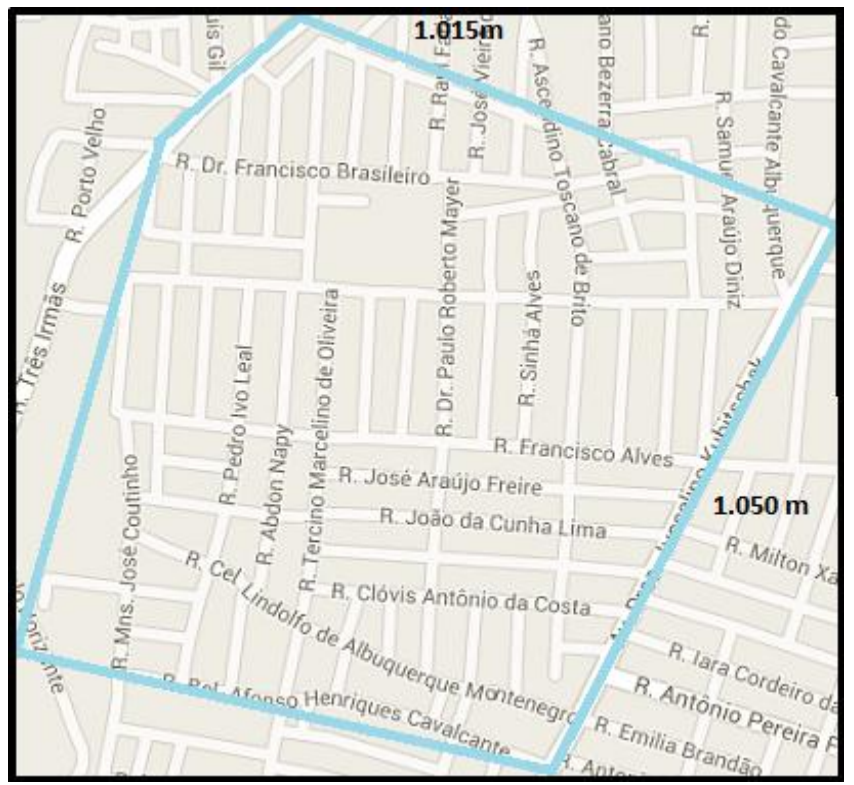

Figura 4. Mapa do bairro Presidente Médici.

Fonte: Imagem adaptada, pelo 8ª ano "C", do Google Maps, 2013.

A adaptação pelos discentes do mapa do bairro foi um consenso dos mesmos quanto aos limites, uma comprovação de que os indivíduos percebem o seu espaço, que armazenam em suas mentes diversos mapas mentais, mas pouco refletem sobre eles.

\section{Paisagem}


Conseguiu-se evoluir do conceito empírico de Paisagem atribuído pelos alunos quando sondados acerca da categoria. Corroborando com Moreira (2007, p. 56), "Não precisamos frequentar a escola para comungar com a Geografia. Nós a percebemos e a aprendemos por força do nosso próprio cotidiano". Descreveram-na como "imagens de lugares bonitos"; "um lugar bonito"; "uma foto"; "um quadro pintado".

Partindo dos conceitos de paisagem atribuídos pelos alunos buscou-se trabalhar na perspectiva da desconstrução da ideia de paisagem como algo sem movimento. "Tudo aquilo que nós vemos, o que nossa visão alcança, é a paisagem. Esta pode ser definida como o domínio do visível, aquilo que a vista abarca. Não é formada apenas de volumes, mas também de cores, movimentos, odores, sons, etc." (SANTOS, 1988, p. 21). Desse ponto de vista, a paisagem representa a sucessão de acontecimentos pretéritos, que resulta na realidade atual.

A sala de aula foi utilizada como exemplo para contribuir para a construção do conceito de paisagem. Solicitaram-se três voluntários para vir até a frente da turma e do mesmo ponto descrever a paisagem visualizada. Cada voluntário fez sua leitura particular, o primeiro atentou para as carteiras quebradas; o segundo observou o número maior de meninas em relação de meninos na sala; 0 terceiro e último, descreveu o estado de conservação da sala.

Discutiu-se acerca do apresentado, chegando-se à conclusão que a leitura de uma paisagem depende do olhar do observador, do quanto àquela imagem representa para ele, do quanto se sabe sobre ela, do quanto se importa com o que se está vendo. Debateu-se a paisagem como representação dos objetos circundantes, resultado de sucessivas alterações, imbuídos de sentimentos e significados. A parte física do espaço ganha vida, refletindo as ações dos indivíduos sobre este.

Sugeriu-se, para os alunos que, na construção de suas leituras sobre determinadas paisagens, sejam formuladas questões acerca do que está sendo visualizado como: "o que aconteceu para que essa paisagem chegasse a este estado? Quais as funções e serviços oferecidos? Quem ocupa esse espaço? 0 que pode ser feito para melhorar? De quem é a culpa ou o mérito por esse resultado?” E outras. 
As discussões em sala de aula serviram de âncora para o desenvolvimento das atividades no laboratório de informática. Foram selecionadas e impressas imagens, exploradas do Google Earth, de tempos diferentes do bairro. Em seguida, disponibilizou-se o material aos alunos para análises das paisagens. As observações unânimes foram às modificações na paisagem a partir do crescimento urbano, além das novas funções de alguns prédios, as melhorias na infraestrutura e outras. Num outro momento, na aula de campo, além das confirmações do visualizado virtualmente teve-se observações acerca dos problemas urbanos, como as questões de acessibilidade e construções irregulares, as margens do canal.

\section{Território}

As discussões e atividades trabalhadas na construção conceitual do território ocorreram na perspectiva do lugar, do que está próximo, partiu-se das relações sócio espaciais vividas e percebidas pelos alunos. Um bom exemplo do trabalho em sala de aula foram as argumentações quanto a influência e o sentimento de posse, poder, que cada aluno tem com relação aos seus lugares na sala, sobre suas carteiras. Percebem-se, cotidianamente, conflitos em defesa de seus territórios. Para Andrade (2004, p. 19), “o conceito de território não deve ser confundido com o de espaço ou de lugar, estando muito ligado à ideia de domínio ou de gestão de determinada área”. Não se confundem, mas estão interligados, os territórios convergem aos espaços e aos lugares.

A luz do pensamento de Raffestin (1993, p. 16), “A territorialidade se manifesta em todas as escalas espaciais e sociais; ela é consubstancial a todas as relações e seria possível dizer que, de certa forma, é a "face vivida" da "face agida" do poder". Dessa forma, paulatinamente, foram-se ampliando os olhares e discussões para escalas maiores dos territórios. Quando questionados sobre os lugares que chamamos de nosso e provocados a respeito de determinadas influências, relações de poder, exercidas por um indivíduo ou um grupo sobre determinado espaço, eles elencaram suas residências; o bairro; 
a cidade; o território nacional e até o "território do tráfico de drogas, realidade presente em seu dia a dia (teve como culminância a apresentação de uma peça teatral sobre o tema).

A conceituação do território, nas atividades no laboratório de informática, transcorreu na perspectiva das identidades e percepções dos estudantes em relação ao bairro Presidente Médici. A visualização das imagens exploradas e adaptadas do Google Earth e do Google Maps permitiu o reconhecimento das paisagens e traçar os limites perimetrais, ou seja, a delimitação do território. Conforme Andrade (2004, p. 20), “A formação de um território dá as pessoas que nele habitam a consciência de sua participação, provocando o sentido da territorialidade que, de forma subjetiva, cria uma consciência de confraternização sobre elas".

Outra questão discutida foi acerca dos territórios religiosos, a forte influência Evangélica do bairro, detém $77 \%$ dos templos religiosos, enquanto que a Igreja Católica, Centro Espírita e a Umbanda cada uma têm representatividade de 7,7\%. (dados da pesquisa in loco, 8 "C", 2013). Essa superioridade evangélica foi questionada e discutida com a visualização de imagens e registradas durante a aula de campo (pesquisa).

A peça teatral, sugestão dos alunos, representou a influência do tráfico de drogas e das relações de poder imbuídas em determinados espaços. Em contrapartida, o trabalho de membros religiosos, outra expressão de influência e poder, surge como refúgio para a libertação dos envolvidos com a prática ilegal e/ou criminosa. Ambas as forças, religião e tráfico, são fenômenos presentes no cotidiano do bairro. 


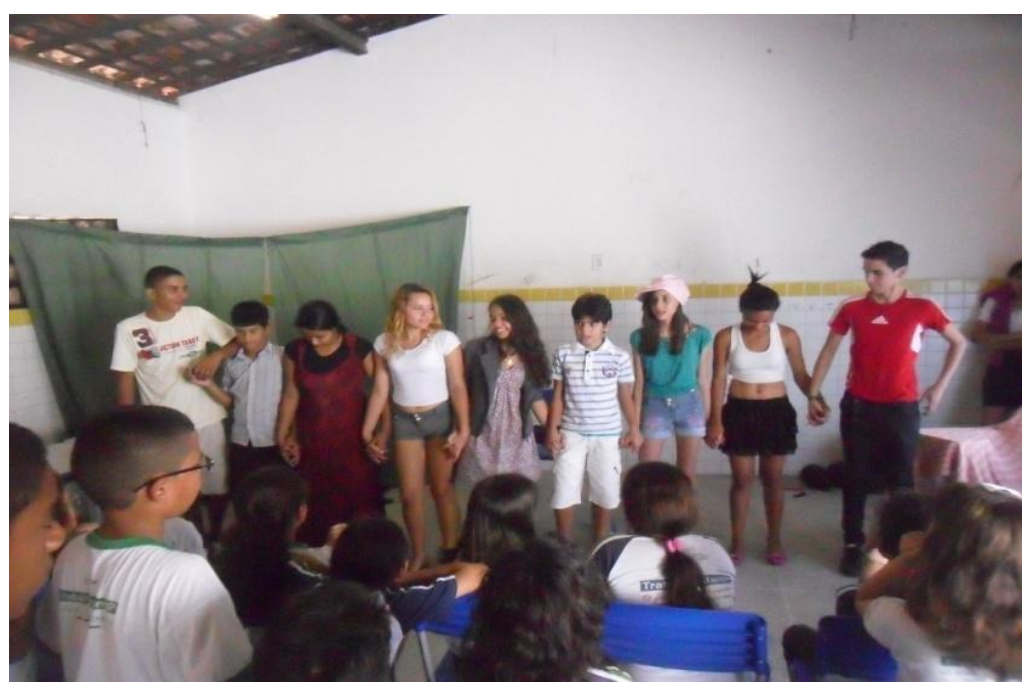

Figura 5. Apresentação da Peça Teatral, na mostra pedagógica. Fonte: Arquivo de Jonas Marques da Penha, 2013.

A religião é representada pelo grande número de templos existentes no bairro, 16,4 templos por km2. Já a existência do tráfico de drogas é percebida nas entrelinhas dos discursos e brincadeiras e durante a aula de campo, quando apontavam para áreas consideradas perigosas. Segundo Raffestin (1993, p. 9), “Todos nós combinamos energia e informação que estruturamos com códigos em função de certos objetivos. Todos nós elaboramos diversas relações de poder”. Diante da exploração das percepções dos alunos, das discussões em sala de aula e da apresentação final da peça foi possível trabalhar o conceito de território.

$\mathrm{Na}$ aula de campo, as relações de pertencimento e a territorialidade dos discentes ficaram nítidas em suas expressões e depoimentos, as identidades e reconhecimento como integrantes do bairro. Em algumas brincadeiras uns ficavam dizendo que outros não eram do bairro por morarem em áreas periféricas, mas os mesmos se defendiam imediatamente, fundamentando, segundo suas postagens entregues pelos correios, como a fatura de energia.

\section{A Linguagem Cartográfica}

Observou-se em sondagens, no decorrer da regência docente, que boa parte dos alunos da turma em análise não tinha domínio da linguagem cartográfica, podendo ser enquadrados como analfabetos 
cartográficos. Segundo Samilli (2010, p. 89), "Os resultados obtidos na pesquisa, que envolveu crianças na faixa etária de 11 a 15 anos, mostraram o baixo nível de leitura de mapas, evidenciando um problema não resolvido na faixa etária anterior (6 a 11 anos)". Diante dessa realidade, a intervenção didático-pedagógica se deu seguindo-se, em parte, a sugestão de alfabetização cartográfica de Samielli (2010):

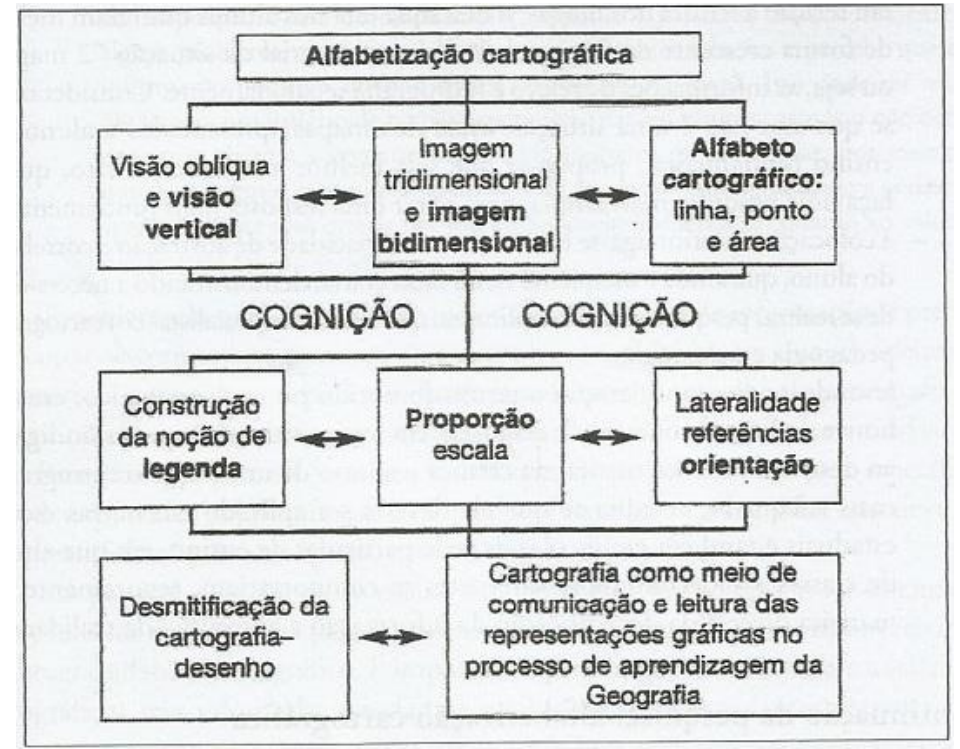

Figura 6. Mapa temático, proposta de alfabetização cartográfica. Fonte: Simielli (1995, apud SIMIELLI, 2010, p. 90).

A sugestão descrita na figura acima foi aplicada, nessa intervenção, de forma supletiva, visto que a proposta original visa ações contínuas iniciadas desde a $1^{\mathrm{a}}$ série. Para Simielli (2010), apenas alunos a $5^{\mathrm{a}}$ série ( $6^{0}$ ano) à $8^{\mathrm{a}}$ série $\left(9^{0}\right.$ ano), quando subsidiados com os conteúdos afins desde as séries iniciais, são capazes de compreender o conceito de escala.

Considerando que o público alvo trata-se de estudantes do $8^{0}$ ano, portanto, esperava-se que já detivessem domínio de certos conteúdos, o que foi o caso. Mesmo muitas vezes desconhecendo conceitos e percepções espaciais básicas, trata-se de jovens com certo grau de maturidade de assimilação. Nessa perspectiva, não houve muitas dificuldades de se trabalhar representação cartográfica. 
Conteúdos como a visão oblíqua (lateral) foi facilmente assimilado, afinal, vive-se cotidianamente visualizando tais imagens. Já a visão vertical, foi apresentada a partir de escalas pequenas como: 0 caderno, o lápis e a borracha. Com o uso do software Google Earth e do Google Maps e suas ferramentas de manipulação das imagens foi possível simular passeios virtuais aéreos e terrestres (imagens tridimensionais), os quais contribuíram para compreensão, representação no plano, mapa (imagem bidimensional) e a confecção da maquete do bairro (Figura 7).

Conteúdos como unidade de medidas métricas, cálculos de área, proporção e escala foram trabalhados individualmente, em sala de aula, e auxiliados pela disciplina de Matemática. A professora acompanhou concomitantemente o desenvolvimento das aulas de Geografia, contemplando em suas aulas os conteúdos afins. 0 resultado dessa parceria superou as expectativas, despertando o interesse de boa parte dos alunos, também pela disciplina de Matemática.

O tema que mais gerou desconforto foi cálculo de área, especialmente durante a confecção da maquete, pois à área do bairro em estudo se apresenta como um pentágono irregular. Dada a complexidade, optou-se por tirar as médias das bases e das laterais do pentágono (mapa do bairro Presidente Médici) e convertê-las em um retângulo e, dessa forma, simplificar a operação. Os cálculos de formas geométricas simples e regulares as dificuldades foram mínimas, iniciando-se com medidas pequenas, como exemplo, a área da capa dos respectivos cadernos e gradativamente ampliando o grau de complexidade.

A Construção da noção de Legenda se iniciou a partir dos símbolos e significados atribuídos, cotidianamente, nos discursos e nas representações gráficas espalhadas pela cidade. Estes foram associados aos símbolos e linguagem dos mapas (pontos, linhas, área). Como atividade em sala foi solicitada a produção do mapa da sala e que para neste fossem criado uma legenda com símbolos representando os limites e os objetos existentes no interior do espaço. Também foram observados e orientados quanto à orientação espacial tanto no espaço real e como no papel (imagem bidimensional).

\section{Maquete}


Recursos inovadores não são sinônimos apenas de novas tecnologias. Foram planejadas e desenvolvidas atividades, como exemplo, a confecção da maquete, a qual para a maioria dos alunos se tratou de uma experiência inédita. Segundo Aquino Jr. (2010, p.78), "O bom professor é aquele que consegue trabalhar a construção do conhecimento com o aluno independentemente do espaço e da infraestrutura que lhe sejam disponibilizados". Munindo-se dos poucos recursos oferecidos pela escola, reaproveitando materiais e com recursos próprios foi possível criar estratégias atrativas para as aulas e abordar com clareza os conteúdos propostos.

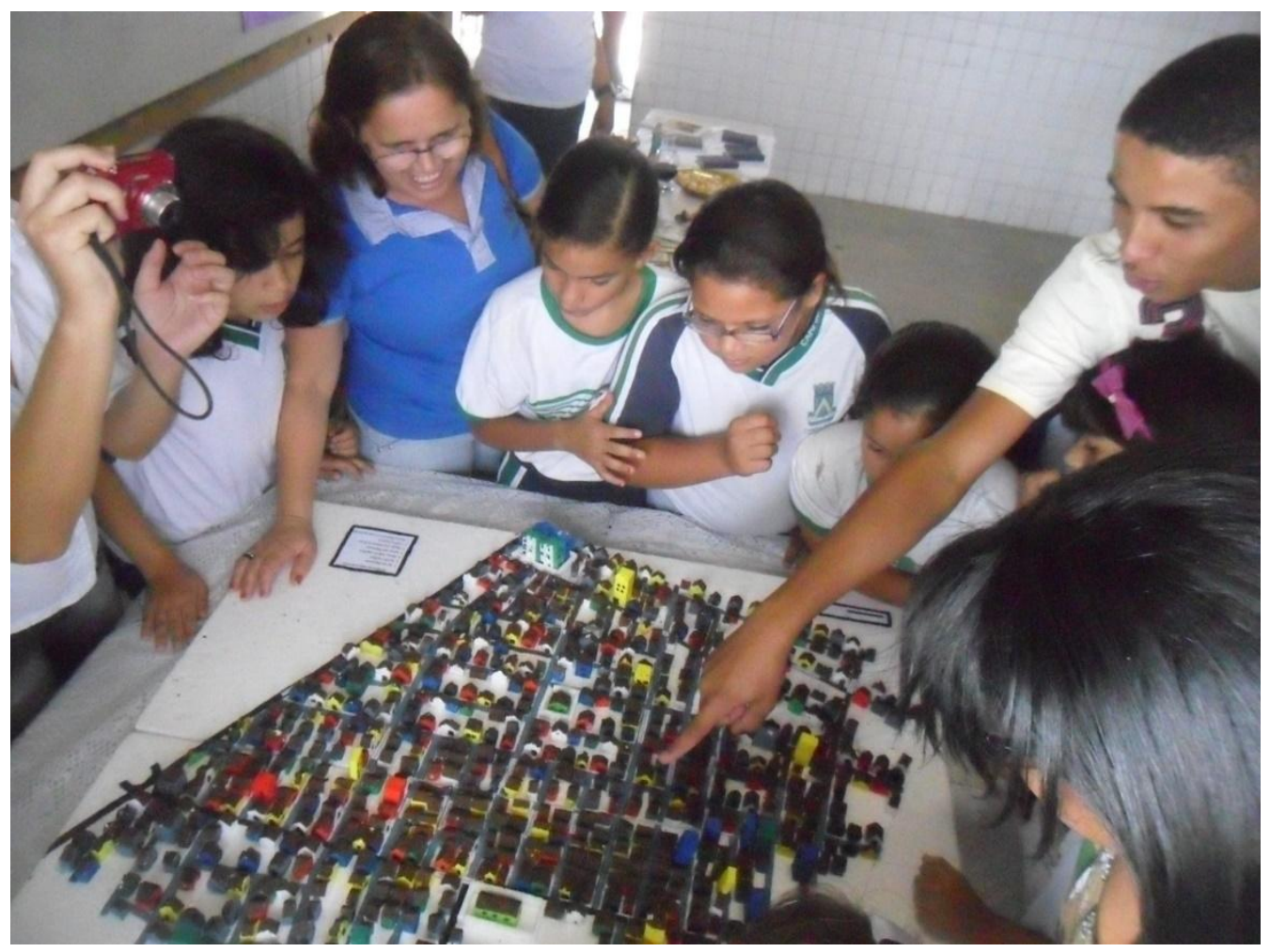

Figura 7. Maquete do bairro Pres. Médici, Campina Grande/PB. Fonte: Arquivo de Jonas Marques da Penha, 2013.

A maquete proporcionou revisões teóricas e práticas de conceitos e fundamentos geográficos. Verificase na Figura 7, que foram atribuídos legenda, escala, referências, trabalhou-se cálculo de áreas etc. Apresenta-se como resultado do processo supletivo de alfabetização cartográfica.

Os softwares, Google Earth e Google Maps, foram de suma importância em todo desenvolvimento da intervenção didático-pedagógico, principalmente o processo de confecção da maquete do bairro. A partir dos mesmos foi possível o acesso e manipulação de imagens de satélite e dados. Em cada etapa 
da confecção da maquete contemplou-se conteúdos específicos os quais forma gradativamente correlacionando-os culminando com a representação tridimensional do lugar.

A característica artística dessa atividade a tornou atrativa, prendendo a atenção e instigando o alunado a estar presente e participar do projeto. Com a intencionalidade de expor e apresentar a maquete, na amostra pedagógica da escola, o trabalho foi encarado com seriedade e entusiasmo.

\section{Avaliação}

As avaliações do professor regente transcorreram de forma contínua e individualizada, a cada etapa do processo de desenvolvimento do trabalho. Corroborando com Vasconcellos (2003), pretendeu-se minimizar as tensões provocadas pelos momentos das avaliações, deixando claro o método e os conteúdos cobrados.

Buscou-se por parte do professor orientador acompanhar de perto todo o processo, como mediador e incentivador. Foram também consideradas as avaliações do corpo docente, durante a culminância do projeto pedagógico da escola - socialização dos resultados na amostra pedagógica e a autoavaliação discente. Infelizmente, boa parte não mostrou maturidade. Os resultados serviram para rever e avaliar os métodos utilizados e como parâmetro para fechamento das notas do $3^{\text {a }}$ bimestre.

\begin{tabular}{|c|c|c|c|c|c|c|c|c|c|c|c|c|}
\hline & & NOTAS & & & $\mathbf{F}$ & $\mathbf{A}$ & $\mathbf{L}$ & $\mathbf{T}$ & $\mathbf{A}$ & $\mathbf{S}$ & \\
\hline$\underline{\text { Alunos }}$ & $\begin{array}{c}1^{\mathbf{0}} \\
\text { Bim. }\end{array}$ & $\begin{array}{c}2^{\mathbf{0}} \\
\text { Bim. }\end{array}$ & $3^{\mathbf{}}$ Bim. & $\underline{\text { Meses }}$ & Fev & $\begin{array}{c}\text { Ma } \\
\text { r }\end{array}$ & Abr & Mai & Jun & Jul & $\begin{array}{c}\text { Ag } \\
\text { o }\end{array}$ & Set \\
\hline $\mathbf{0 1}$ & 7,0 & 4,7 & $\underline{8,2}$ & & 00 & 02 & 04 & 02 & 00 & $\underline{00}$ & $\underline{00}$ & $\underline{00}$ \\
\hline $\mathbf{0 2}$ & 8,5 & 7,0 & $\underline{8,5}$ & & 00 & 00 & 03 & 01 & 02 & $\underline{00}$ & $\underline{00}$ & $\underline{00}$ \\
\hline $\mathbf{0 3}$ & 7,7 & 8,7 & $\underline{9,2}$ & & 02 & 02 & 03 & 04 & 02 & $\underline{00}$ & $\underline{00}$ & $\underline{00}$ \\
\hline $\mathbf{0 4}$ & 9,0 & 5,7 & $\underline{8,0}$ & & 00 & 00 & 04 & 01 & 02 & $\underline{00}$ & $\underline{00}$ & $\underline{00}$ \\
\hline $\mathbf{0 5}$ & 8,0 & 2,2 & $\underline{8,0}$ & & 01 & 02 & 03 & 05 & 04 & $\underline{04}$ & $\underline{00}$ & $\underline{00}$ \\
\hline $\mathbf{0 6}$ & 9,2 & 7,2 & $\underline{9,2}$ & & 00 & 00 & 03 & 00 & 02 & $\underline{00}$ & $\underline{00}$ & $\underline{00}$ \\
\hline $\mathbf{0 7}$ & 7,7 & 6,2 & $\underline{9,0}$ & & 00 & 00 & 04 & 05 & 02 & $\underline{02}$ & $\underline{06}$ & $\underline{00}$ \\
\hline $\mathbf{0 8}$ & 6,0 & 6,5 & $\underline{7,7}$ & & 00 & 00 & 04 & 04 & 04 & $\underline{00}$ & $\underline{00}$ & $\underline{00}$ \\
\hline $\mathbf{0 9}$ & 7,7 & 5,0 & $\underline{7,7}$ & & 00 & 04 & 03 & 05 & 02 & $\underline{02}$ & $\underline{02}$ & $\underline{02}$ \\
\hline $\mathbf{1 0}$ & 7,7 & 5,7 & $\underline{8,5}$ & & 00 & 03 & 04 & 03 & 02 & $\underline{02}$ & $\underline{00}$ & $\underline{00}$ \\
\hline
\end{tabular}




\begin{tabular}{|c|c|c|c|l|c|c|c|c|c|c|c|c|}
\hline $\mathbf{1 1}$ & 8,0 & 7,5 & $\underline{8,5}$ & & 00 & 02 & 05 & 06 & 06 & $\underline{00}$ & $\underline{00}$ & $\underline{00}$ \\
\hline $\mathbf{1 2}$ & 8,5 & 8,7 & $\underline{8,5}$ & & 00 & 00 & 03 & 01 & 02 & $\underline{00}$ & $\underline{00}$ & $\underline{00}$ \\
\hline $\mathbf{1 3}$ & 6,7 & 6,5 & $\underline{7,7}$ & & 02 & 06 & 06 & 03 & 06 & $\underline{04}$ & $\underline{02}$ & $\underline{00}$ \\
\hline $\mathbf{1 4}$ & 3,5 & 6,5 & $\underline{8,0}$ & & 00 & 03 & 09 & 05 & 02 & $\underline{00}$ & $\underline{02}$ & $\underline{00}$ \\
\hline $\mathbf{1 5}$ & 8,2 & 5,7 & $\underline{7,0}$ & & 01 & 04 & 05 & 05 & 06 & $\underline{00}$ & $\underline{00}$ & $\underline{02}$ \\
\hline & & & & & & & & & & & & \\
\hline$\underline{\text { Médias }}$ & $\mathbf{7 , 7}$ & 6,2 & $\underline{\mathbf{8 , 2}}$ & $\underline{\text { Médias }}$ & $\mathbf{0 , 4}$ & $\mathbf{1 , 8}$ & $\mathbf{4 , 2}$ & $\mathbf{3 , 3}$ & $\mathbf{2 , 9}$ & $\underline{\mathbf{0 , 9}}$ & $\underline{\mathbf{0 , 8}}$ & $\underline{\mathbf{0 , 3}}$ \\
\hline
\end{tabular}

Quadro 2. Rendimentos Bimestrais dos Docentes.

Fonte: Elaborado por Jonas Marques da Penha, a partir dos registros do diário escolar (2013).

No contexto geral, as atividades ocorreram dentro da normalidade, sem problemas que as comprometessem. No decorrer do processo de intervenção foi registrado maior rendimento, em relação aos bimestres anteriores, assiduidade e efetiva participação da turma, o que repercutiu na qualidade do aprendizado e, consequentemente, no rendimento dos alunos.

Os resultados, média de nota, da turma no terceiro bimestre, período da pesquisa-ação, superaram os dois bimestres anteriores. Percebe-se, no Quadro - 3, que o número de faltas no início do ano é relativamente baixo, provavelmente pela expectativa do "novo". Constatou-se que gradativamente, o número de falta vai se elevando, durante os cinco primeiros meses do ano seguinte, $1^{\circ}$ e $2^{\circ}$ (bimestre), a média de faltas da turma oscila entre 1,4 e 4,$2 ;$ já durante o $3^{\circ}$ bimestre, o qual foi trabalhado com o projeto, essa média manteve-se em declínio, sendo no primeiro mês, Julho, 0,9; em Agosto 0,8 e por último a média do mês de Setembro, 0,3.

Analisando de forma pontual destacam-se o crescimento intelectual e o interesse em participar das aulas pelos alunos 01,05 e 14 . Respectivamente no $1^{0}$ semestre estiveram ausentes em 8, 15 e 19 aulas e obtiveram as seguintes médias nesse período 5,8; 5,1 e; 5,0 .

Com o projeto de intervenção em prática emergiram resultados surpreendentes. Os alunos acima citados no $3^{\circ}$ bimestre progrediram respectivamente para as médias 8,$2 ; 8,0 ;$ e 8,0. Este gradiente crescente de resultados atribui-se ao envolvimento que se deu à medida que o alunado se percebe no projeto e visualizam objetivos a serem alcançados em curto prazo, por exemplo, a exposição dos resultados na mostra pedagógica. 
Os dados analisados apresentam a relação inversamente proporcional entre as médias de faltas e médias de notas, quanto maior o número de falta menor os rendimentos, as notas. Verificou-se que o baixo rendimento é, também, consequência do déficit de atenção do alunado. Ficou comprovado que a falta de interesse discente está, em parte, relacionada à didática do professor (a).

\section{CONSIDERAÇÕES FINAIS}

Diante das inúmeras transformações da sociedade os(as) professores(as) tem o desafio de rever e refletir cotidianamente sobre sua prática docente, fundamentos da pesquisa-ação, uma autocrítica que tende a contribuir para o crescimento profissional. Precisa-se questionar se os serviços que tem sido oferecido estão convergindo com as necessidades e interesses do alunado contemporâneo. Deve-se atentar para as identidades e identificações do jovem contemporâneo e inserir a prática docente recursos didáticos que atendam seus anseios, no caso, as novas tecnologias midiáticas.

A juventude moderna, mediante a acessibilidade as novas tecnologias, tem acesso a uma série de informações prontas e apresentadas de forma atrativa, lúdica e bem mais interessante que as aulas que geralmente nos propomos a ministrar na Escola. Nesse contexto o desafio da escola deve ser de tornarse um lugar, espaço imbuído de identidades territoriais e relações de pertencimento entre seus atores.

O aluno precisa se sentir em casa, "à vontade". O espaço escolar precisa ser atraente e os conteúdos trabalhados precisam ter significância, um currículo que contemple as identidades e identificações comuns aos estudantes sem se desprender da heterogeneidade. Num processo, ensinar-aprender, os profissionais da educação devem atuar como orientadores e mediadores na construção do conhecimento.

No ensinar-aprender na Geografia Escolar, a aproximação dos construtores do conhecimento ao objeto de estudo é de fundamental importância e relevância. 
O êxito do trabalho atribuiu-se principalmente ao uso de novas tecnologias aliado as aulas de campo e ao fato da área de estudo ter sido um espaço conhecido, que faz parte da dinâmica cotidiana dos envolvidos no processo; e ás atividades artísticas e lúdicas desenvolvidas. Pode-se dizer que foram diferenciais que contribuíram fortemente para, o despertar, do interesse dos estudantes-pesquisadores.

Dentre as atividades orientadas na intervenção destacaram-se como recursos didáticos potenciais para o ensino de Geografia, os softwares (Google Earth e Google Maps) e a confecção da maquete do bairro. Os primeiros facilitaram a acessibilidade e manipulação de imagens e dados. A maquete promoveu uma revisão geral das teorias, discutidas em aulas expositivas e de campo, e a aplicação prática das mesmas. O processo de confecção de uma maquete possibilita inserir gradativamente, a cada etapa, diversos conceitos geográficos discutindo-os, relacionando-os e aplicando-os na prática.

Não se pode deixar de exaltar a importância da interdisciplinaridade no decorrer das atividades, o apoio intelectual e logístico do corpo docente da instituição. A construção do conhecimento não se dá de forma unilateral, há interação e interdependência entre as disciplinas.

O desafio foi explorar o conhecido e compreender o global a partir do que está próximo, o lugar, a escala local e utilizar recursos acessíveis aos alunos. Procedimentos didático-metodológicos que atraíram o alunado para as ações propostas, consequentemente reduzindo a evasão escolar e conduzindo-lhes a melhores rendimentos e crescimento intelectual, por exemplo, teve aluno que no $1^{0} \mathrm{e}$ $2^{\circ}$ bimestre somou 19 faltas nas aulas da disciplina de Geografia e suas médias respectivamente 3,5 e 6,5 , já durante o projeto esteve em $100 \%$ das aulas, melhorando o crescimento intelectual e elevando sua média para 8,0.

Ações como as apresentadas neste trabalho buscam fazer uso de recursos vinculados a novas metodologias para criar um elo entre o espaço escolar e a dinâmica diária de sua clientela, visto que há um fascínio juvenil sobre estas e o acesso é cada vez mais precoce. 
Diferente dos alunos, muitos professores (as), por motivos diversos, não tem o acesso e/ou domínio sobre algumas ferramentas tecnológicas, o que tem dificultado a inserção destas como recursos didáticos nas aulas. Afirmo que sem os recursos didáticos utilizados seria inviável esta proposta de intervenção, pois demandaria mais tempo, disponibilidade, suporte logístico e recursos para conseguir as informações e imagens disponíveis nos mesmos.

Dentro do contexto das culturas religiosas do bairro, além, das discussões acerca do território foi, também, brevemente abordada temática do etnocentrismo na perspectiva de discutir as questões culturais. Viu-se que o contato direto com a cultura do "outro", com as diferenças, promove um maior conhecimento da realidade e dos direitos universais, um convite a reflexão quanto às opções, convicções e culturas coexistentes num mesmo espaço geográfico. Questões que podem ser melhores trabalhadas numa pesquisa futura.

O aluno precisa ser visto e compreendido como agente principal na construção do conhecimento, que seus conhecimentos prévios, adquiridos empiricamente cotidianamente venham a ser o ponto de partida na produção de um novo conhecimento. É claro, intermediado, incentivado, questionado e orientado pelo professor, no intuito de juntos colher resultados que os conduza a autonomia.

\section{REFERÊNCIAS}

ALMEIDA, R. D. A propósito da questão teórico-metodológica sobre o ensino de geografia. Revista Terra Livre - prática de ensino em geografia, n. 8, edição 1991, p.83-90.

ANDRADE, M. C de. A Questão do Território. In: A questão do território no Brasil. 2. ed. São Paulo: HUCITEC, 2004. p. 13-19.

AQUINO JÚNIOR, A. O Aluno, o professor e a escola. In: PASSINI, E. Y. (Org.). Prática de ensino de geografia e estágio supervisionado. 2. ed. São Paulo: Contexto, 2010. p. 78-85.

BOCK, A.; FURTADO, O.; TEXEIRA, M. A. Psicologia da Aprendizagem. In: . Psicologias: uma introdução ao estudo de psicologia. 3. ed. São Paulo: Saraiva, 2002. p. 114-129.

BRABANT, J. Crise da geografia, crise da escola. In: OLIVEIRA, A. U. (Org.). Para onde vai o ensino de geografia? São Paulo: Contexto, 1989.

BRASIL, Secretaria de Educação Fundamental. Parâmetros Curriculares Nacionais. Geografia. Brasilia: MEC/SEF, 1998. 
CALlAI, H. C. A Geografia e a escola: muda a Geografia? Muda o ensino? Revista Terra Livre. São Paulo, 2001. p. 134151.

CARLOS, A. F. A. Definir o Lugar? In: O lugar no/do mundo. São Paulo: Labur, 2007. p.16-20.

CASSAB, C. Reflexões sobre o Ensino de Geografia. Revista Santa Maria: Geografia: ensino e pesquisa, v. 13, n. 1, p. 4350,2009 .

CAVALCANTI, L. S. Geografia, escola e construęão de conhecimentos. 17. ed. Campinas, SP: Papirus, 1998.

HALL, S. A identidade cultural na pós-modernidade. 11. ed. Rio de Janeiro, RJ: DP\&A. 2006.

KAERCHIER, N. A. A Geografia Escolar: gigante de pés de barro comendo pastel de vento num fast food? Revista Terra Livre, n. 28, v. 1, 2007, p.27-44.

KIMURA, S. Faze-pensar: fonte do ensinar-aprender. In: Geografia do ensino básico: questões e propostas. São Paulo: Contexto, 2008. p. 44-67.

LEMos, S. Nativos Digitais X Aprendizagens: Um Desafio Para A Escola. B. Téc. Senac: a R. Educ. Prof., Rio de Janeiro, v. 35, n. 3, p. 38-47, set./dez. 2009. Disponível em: http://www.senac.br/BTS/353/artigo-04.pdf >. Acesso em: 20 dez. 2013.

LUCKESI, C. C. Projeto Político-Pedagógico da escola e seus Parâmetros para a avaliação da atividade docente e discente. In: Avaliação da Aprendizagem: componente do ato pedagógico. São Paulo: Cortez, 2011. p. 27-58.

MORAN, J. M. Os novos espaços de atuação do educador com tecnologias. In: Endipe - Encontro Nacional de Didática e Prática de Ensino, 12² 2004. PUCPR - Pontifícia Universidade Católica do Paraná. Anais... Curitiba: Champagnat, 2004.

MOREIRA, R. 0 que é Geografia. In: . 14. ed. São Paulo: Brasiliense, 2007. (Coleção primeiros passos, n.48).

PINHO, W. et al. Cibersepaço e as relações sociais de lazer. In: COSTA, A. et al (org.). Mídia, cultura e imaginário urbano. Campina Grande: SEE/PB-UEPB, 2013. p. 65-73.

PONTUSCHKA, N. P.; PAGANELli, T. L. e CACETE, N. C. A Geografia como ciência e disciplina escolar. In: Para ensinar e aprender Geografia. São Paulo: Cortez, 2009. p. 35-104.

PRENSKY, M. Nativos Digitais, Imigrantes Digitais. De On the Horizon (NCB University Press), Vol. 9 No. 5, Out. 2001.

RAFFESTIN, C. O Território e o Poder. In: Por uma Geografia do poder. São Paulo: Ática, 1993.

SAMIELLI, M. E. O Mapa Como Meio de Comunicação e a Alfabetização Cartográfica. In: ALMEIDA, R. D. Cartografia Escolar. São Paulo: Contexto, 2010. p. 71-93.

SANTOS, M. Metamorfoses do espaço habitado: fundamentos teóricos e metodológicos da geografia. São Paulo: Hucitec, 1988.

SATO, E.; FORNEL, S. Conhecimento do espaço escolar. In: PASSINI, E. Y. (Org.). Prática de ensino de geografia e estágio supervisionado. 2ed. São Paulo: Contexto, 2010. p. 52-57.

SAVIANI, D. O trabalho como principio educativo frente às novas tecnologias. In: FERRETTI, C. et. al. (Org.). Novas tecnologias, trabalho e educação: um debate multidisciplinar. Petrópolis: Vozes, 1994. p. 151-168. 
TERUYA, T. et al. Sujeitos da juventude, mídia e escola. In: COSTA, A. et al (Org.). Mídia, cultura e imaginário urbano. Campina Grande: SEE/PB-UEPB, 2013. p. 77-83.

TRIPP, D. Pesquisa-ação: uma introdução metodológica. Revista Educação e Pesquisa, São Paulo, v. 31, n. 3, p. 443-466, set./dez. 2005.

TUAN, Y. F. Espaço e Lugar: a perspectiva da experiência. São Paulo: DIFEL, 1983.

VASCONCELLOS, C. Conteúdo e forma da avaliação. In: Avaliação da Aprendizagem: práticas e mudanças - por uma práxis transformadora. 5 ed. São Paulo: Libertad, 2003. p. 91-132. (Coleção Cadernos Pedagógicos do Libertad, v.6).

VIGOTSKY, L. S. A Formação Social da Mente. São Paulo: Martins Fontes, 1989. 